Original Article

\title{
CHARACTERIZATION OF NATIVE HONEY BEE SUBSPECIES IN REPUBLIC OF BENIN USING MORPHOMETRIC AND GENETIC TOOLS
}

\author{
Felicien Amakpe ${ }^{1}$ \\ Lina De Smet ${ }^{1 \star}$ \\ Marleen Brunain ${ }^{1}$ \\ Frans J. Jacobs ${ }^{2}$ \\ Brice Sinsin ${ }^{3}$ \\ Dirk C. de Graaf ${ }^{1}$ \\ ${ }^{1}$ Ghent University, Laboratory of Molecular Entomolgy and Bee Pathology, \\ Krijgslaan 281 S2, 9000 Gent, Belgium \\ ${ }^{2}$ Ghent University, Honey Bee Valley, Krijgslaan 281 S33, 9000 Gent, Belgium \\ 3University of Abomey, Laboratory of Applied Ecology, 01 B.P. 526, \\ Cotonou, Benin \\ *corresponding author: lina.desmet@ugent.be \\ Received: 03 October 2017; accepted: 03 January 2018
}

A bstract

Morphometric characteristics combined with genetic markers are powerful tools used for determining honey bee subspecies. Bees samples collected from 94 established apiaries distributed throughout all of the Republic of Benin were morphometricaly characterized using seven parameters and the COI-COII regions of mitochondrial DNA were sequenced. Based on the morphometric data the native honey bees could be divided into three distinct ecotypes - the Benino-dry-tropical-ecotype in the north, the Benino-Sudanian-ecotype in the central part and the Benino-Sudano-Guinean-ecotype in the south. The DNA COI-COII regions sequence analyses confirmed that the honey bee population of the Republic of Benin belongs to different mitotypes but do not correspond with the determined ecotypes. We could determine three new haplotypes which missed the $P_{0}$ segment but the $Q$ region was duplicated or triplicated. Phylogenetic analyses clustered them together in the A evolutionary lineage. In conclusion, morphometric and genetic analysis of the native West African honey bees indicated that each of the different mitotypes was able to adapt to the different ecological conditions in the country by morphometric adjustments.

Keywords: Apis mellifera, ecotype, Republic of Benin, subtype

\section{INTRODUCTION}

The honey bees, Apis mellifera (L.), are key pollinators and their contribution to the worldwide agricultural production is estimated to more than \$200 billion per year (Gallai et al., 2009). They fulfil major roles in the ecosystem services and contribute to the human needs. Beekeeping sustainability depends on the diversity in the honey bee populations as this reinforces their resistance to diseases and improves hive product yields (Jaffe et al., 2009; Moritz et al., 2010). Unfortunately, very little is known on the global genetic and morphometric variations which govern the evolutionary history, the adaptation to the changing climatic conditions and resistance to diseases (Wallberg et al., 2014). With the use of morphometric methods, honey bees have been divided in five evolutionary lineages which are the $M$ (West Mediterranean and West European subspecies), the $C$ (North Mediterranean and Central European bees), the $O$ (the Oriental bees), the $Y$ (the Ethiopian honey bees) and $A$ which regroups the remaining African honey bees (Arias \& Sheppard, 1996; Franck et al., 2000b; Garnery et al., 1993).

For the African countries in general and West Africa in particular, the genetic and morphometric knowledge on honey bees is poorly documented and mainly done at the African bio-geographic level. Until now, twelve African honey bee subspecies have been described and 
the current racial map shows that the adansonii subspecies is spread from the Democratic Republic of Congo to Senegal (Meixner et al., 2011; Ruttner, 1988). The lack of accuracy in the morpho-genetic diversity of the honey bee populations makes it difficult to control genetic erosion and to get insight into the factors that govern the well-known resistance of the African honey bees to diseases, their aggressiveness, hygienic behaviour and high tendency to abscond (Chemurot et al., 2016; Fazier et al., 2010; Strauss et al., 2013). An evaluation of such diversity at a smaller geographic level is necessary because the high ecological diversity in large areas can lead to allopatric conditions that could induce subspeciation in $A$. mellifera populations.

The honey bees in the Republic of Benin were classified as $A$. mellifera adansonii based on morphometric measurements by Villières (1987). Further studies were limited to measurements of key body parts in isolated villages located in the centre and the north of the country and provided no further characterization (Amakpe, 2010; Hounpke et al., 2007; Paraïso et al., 2011, Paraïso et al., 2017).

Morphological characterization is still considered as a very important method in the classification of honey bees with more than forty useful parameters (Adl et al., 2007; Fresnaye, 1981; Meixner et al., 2011). Among them, wing length, wing width, cubital veins, femur length, basitarsus and tibia lengths of workers are the easiest and the most non-biased quantitative parameters (Adl et al., 2007; Francoy et al., 2008; Sheppard \& Smith, 2000). However this approach is not well suited to characterizing honey bees at a subspecies level and to studying phylogenetic relationships (Danforth et al., 2013; Franck et al., 2000a; Miguel et al., 2011). A more accurate and reliable method for discriminating honey bee subspecies and their evolutionary lineage is the use of the sequence of the mtDNA COI-COII intergenic region (Cornuet \& Garnery, 1991; Garnery et al., 1993). Variations in the sequence of this region can be used for differentiating among the five honey bee lineages and discriminat- ing among $A$. mellifera subspecies (Franck et al., 2000a; Franck et al., 2000b; Garnery, Cornuet, \& Solignac, 1992; Sheppard \& Smith, 2000, Alattal et al., 2014). The objective of this research was to determine the morphometric and genetic diversity of the native honey bee populations in the Republic of Benin. Our hypothesis was that the geographic location would be reflected in patterns of honeybee variation on a morphometric and molecular level.

\section{MATERIAL AND METHODS}

\section{Sample collection}

The study covered the entire Republic of Benin from north to south. Beekeeping in the country started recently and is mainly performed by small-scale peasants using traditional and Kenyan top bar hives and there have been no report of bees introduced from other countries (Amakpe, Zuber, \& Jacobs, 2008). In addition queens are not exchanged between beekeepers as queen rearing is unknown in the country which guarantees the study of the native population. The studied bees were collected from 94 established apiaries distributed over the country at an average distance of $40 \mathrm{~km}$ from one another ranging from $5 \mathrm{~km}$ to $80 \mathrm{~km}$ (Fig. 1). At each apiary, the hives were baited and left freely colonised by natural swarms. For the bee collection, at least 100 young bees were sampled from the inside of one randomly chosen hive per apiary with an adapted hand aspirator. The sampled bees were immediately conserved in $70 \%$ ethanol until further use.

\section{Morphometric study}

The morphometric measurements were performed on twenty randomly selected bees from each colony. The right forewing and the right hind leg of each bee were cut. They were mounted and fixed on slides by covering them with a thin transparent adhesive tape. The bee parts were scanned with a micro numeric microscope camera CCMEX-1300 at a total magnification of $60 x$ as described in the instructions (Javier et al., 2007). The scanned digital images were measured with image focus V3.0 software. The classic morphological traits were 


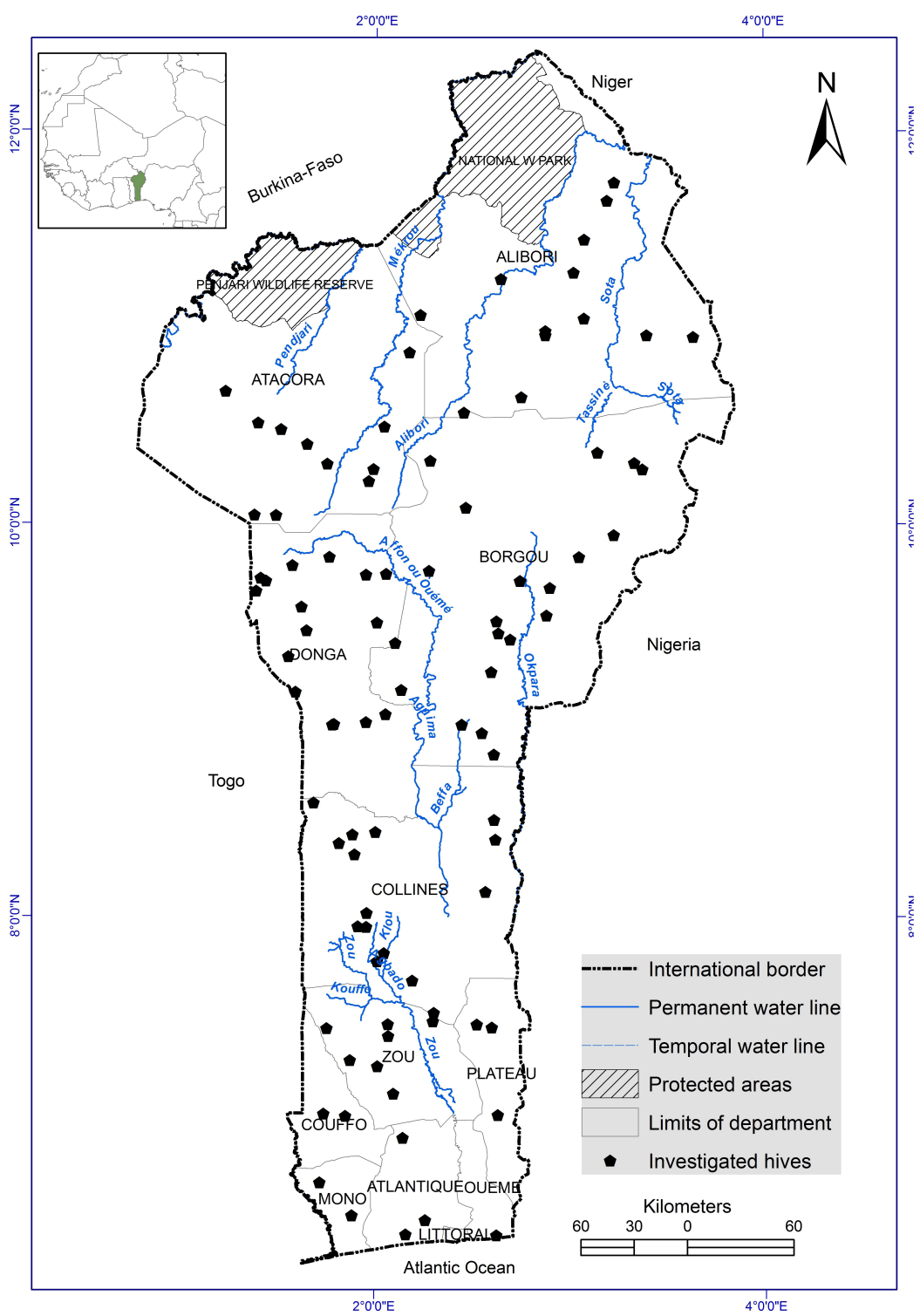

Fig. 1 Locations of the investigated apiaries in the Republic of Benin.

analysed, on the right forewing - wing length (WL), wing width (WW) and the cubital veins "a" and " $b$ " and on the right hind leg - femur length $(F L)$, tibia length (TL) and basitarsus length (BL). In addition, two parameters were calculated; the total leg length per bee (TLL) equalled the sum of FL,TL and BL and the cubital index per bee was defined as $\mathrm{Cl}=\mathrm{b} / \mathrm{a}$.

The repeatability of the measuring methods was obtained by using the same measuring tools (Microscopes, photo adapter, slides and adhesive cover) and the same operator who performed the operation during the same period of the day (British Standards Institution (1975); (Bland \& Altman, 1986; Ogbuehi \& Osuagwu, 2012). The repeatability was first tested and accepted $(\ulcorner \%<0.01)$ by performing twice the different measurements on two groups of ten bees from one colony.

The morphometric data analysis was performed with $\mathrm{R}$ 3.0.3 software. The colony sample means and standard deviation were first calculated and used as representative estimates for each colony. The entire morphometric parameters were first submitted to a stepwise canonical discriminant analysis for the identification of the body parts that add the highest predictive power to the discriminant functions. The colonies were classified into ecotypes through the cluster analysis based on the Euclidian distance and the Wards method (Bray \& Curtis, 1957; Shrestha \& Kazama, 2007). This served to identify homogeneous colony clusters (groups) which were assimilated to the different honey bee morpho-ecotypes.

The colonies that made up each group of the discriminant analysis were given a specific symbol in the feature class after their geographic coordinates were located in the country "shape file" by ArcGIS $9.02^{\circledast}$. The distribution of the cluster plots in the country map was visually inspected and the concentration area of each symbol was assimilated to the corresponding ecotype region. The south-north, west-east and topographic morphometric gradients were analysed through multiple regression among the environmental parameters (longitude, latitude, and elevation) and the body parts that best discriminated the colony groups (Meixner et al., 2011; Ruttner, Tassencourt, \& Louveaux, 1978).

\section{Molecular study}

One bee from each colony analyzed during the morphometric measurements was used in the genetic characterization. Because the bees 
Stepwise discriminant analysis matrix of the morphometric parameters

Table 1.

\begin{tabular}{cccc}
\hline Morphometric characteristics & F statistics & P value & Wilks'lambda \\
\hline Total leg length & 116.03 & $<0.001$ & 0.28 \\
Wing length & 15.85 & $<0.001$ & 0.21 \\
Cubital vein "b" & 3.56 & 0.033 & 0.19 \\
Wing width & 0.18 & 0.833 & - \\
Cubital vein "a" & 0.28 & 0.757 & - \\
Femur length & 0.79 & 0.456 & - \\
Tibia length & 0.93 & 0.398 & - \\
Basitarsus length & 0.60 & 0.551 & - \\
Cubital index & 0.28 & 0.758 &
\end{tabular}

had been preserved in ethanol, they were first washed in PBS for 72 hours before DNA was extracted as described by Garnery et al. (1991). Briefly, DNA was extracted by grinding one bee in $1 \mathrm{ml}$ of $M$ TrisHCl (pH 8.0), 10 mM EDTA, 100 $\mathrm{mM} \mathrm{NaCl}, 0.1 \%$ SDS, $50 \mathrm{mM}$ DTT and $0.25 \mathrm{mg} /$ $\mathrm{ml}$ proteinase $\mathrm{K}$. The extracts were incubated for four hours at $37^{\circ} \mathrm{C}$ and then centrifuged for 5 min at 500 g. Deproteinization was performed with two phenol-chloroform extractions. DNA was precipitated with ethanol overnight at $-20^{\circ} \mathrm{C}$, pelleted (30 min at 18,000 g), rinsed with $70 \%$ ethanol and after drying resuspended in 1 $\mathrm{ml}$ of TE (10 mM Tris, 1 mM EDTA, pH 8).

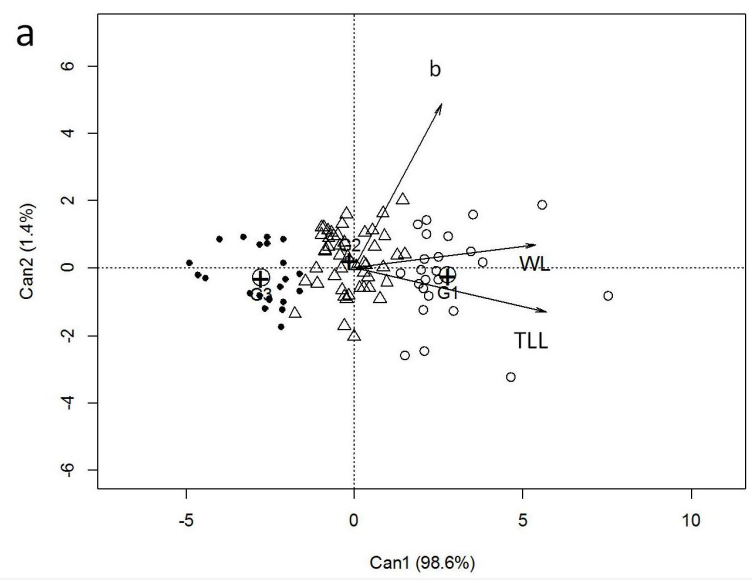

\section{PCR amplification and sequencing}

The mtDNA region including the tRNAleu gene, the COI-COll intergenic region and the $5^{\prime}$ end of the COll subunit gene was PCR-amplified with the use of gene-specific primers E2 (5'-GGCAGAATAAGTGCATTG-3') and H2 (5'-CAATATCATTGATGACC-3') (Garnery et al., 1991). The $25 \mu$ PCR reaction contained $2.5 \mu$ 10x buffer, $2 \mathrm{mM} \mathrm{MgCl}, 25 \mathrm{pM}$ of primers $\mathrm{E} 2$ and $\mathrm{H} 2,25$ $\mathrm{nM}$ of each dNTP and 1.25 units of HotStarTaq DNA Plus polymerase (Qiagen) and $1 \mu$ of DNA extract as template. The temperature cycling protocol was set as follows: 2 min at $95^{\circ} \mathrm{C}, 45$ $\mathrm{s}$ at $95^{\circ} \mathrm{C}, 45 \mathrm{~s}$ at $54^{\circ} \mathrm{C}, 1 \mathrm{~min}$ at $72^{\circ} \mathrm{C}-35$

b

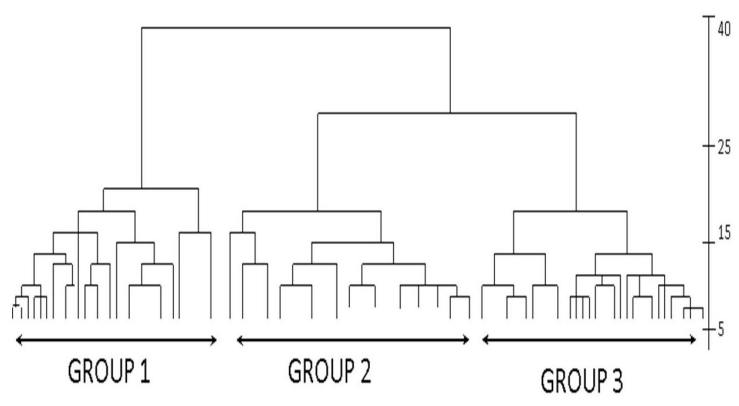

Fig. 2 Discriminant analysis of the Benin honey bees (panel a) and the corresponding dendrogram (panel b). Group 1 (G1) is represented by open circles, group 2 (G2) by triangles and group 3 (G3) by filled dots in the discriminate analysis. TLL: total leg length; b: cubital vein "b"; Can: canonical axe. 


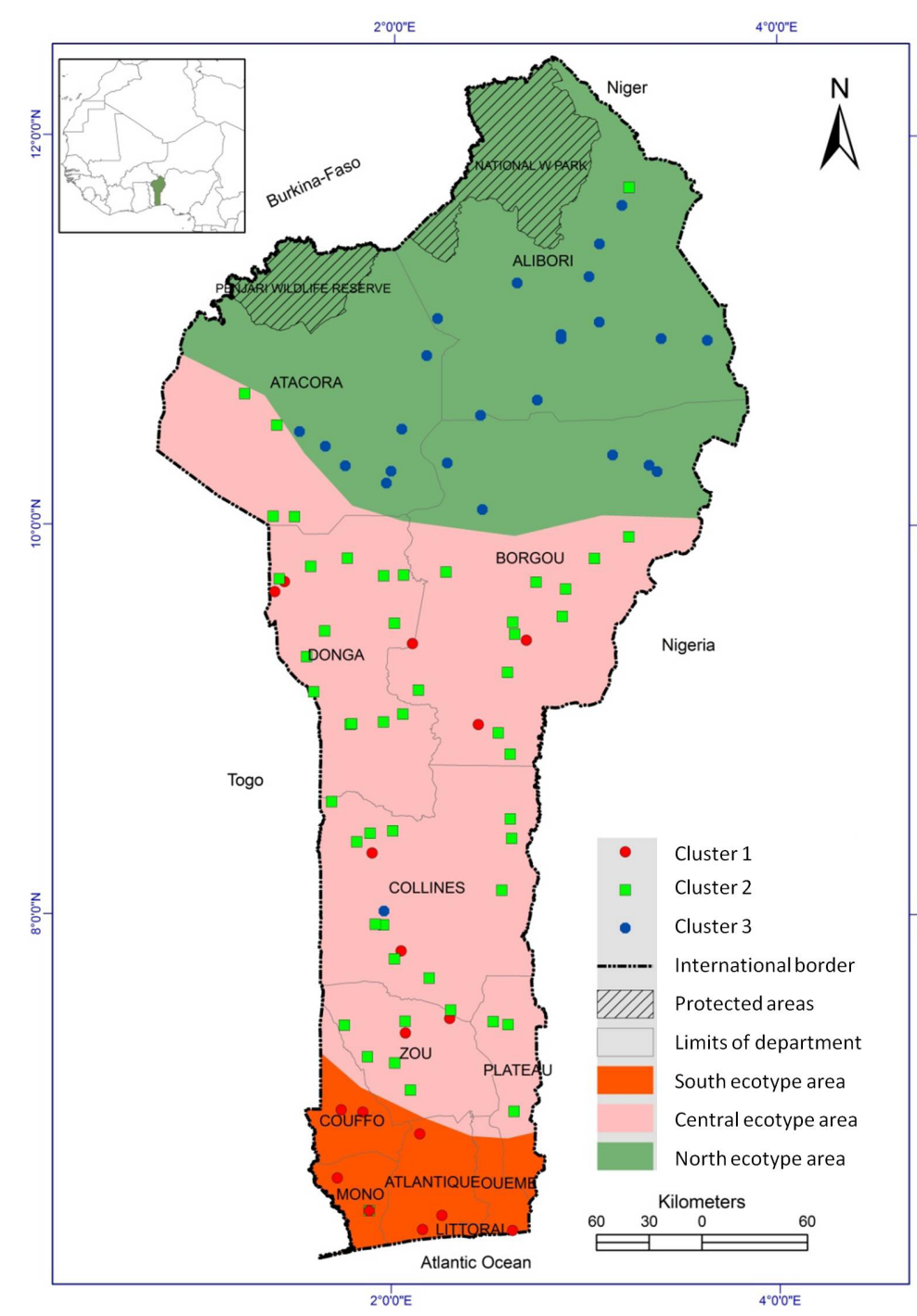

Fig. 3 Spatial analysis of the different bee ecotypes. The blue dots represents group 1 of the discriminant analysis and correspond to the Benino-dry-tropical-ecotype. The green squares (group 2 of the discriminant analysis) are mixed with group 3 (represented by red dots). Group 2 is concentrated in the center and correspond to the Benino-Sudanian-ecotype while group 3 correspond to the Benino-Sudano-Guineanecotype.

cycles, ad $5 \mathrm{~min}$ at $72^{\circ} \mathrm{C}$. A fraction of the PCR product was analyzed on a $1 \%$ agarose gel as quality control. PCR products were sequenced in both directions by GATC biotech with the use of a ABI 3730xI DNA genetic analyser (Applied Biosystem). Sequences were assembled using Vector NTI software. They were BLASTed and compared with the sequences available in the GenBank database (NCBI), and an in silico Dral restriction analysis was performed. The resulting restriction fragments were used to determine the different haplotypes (Garnery et al., 1998).

\section{Phylogenetic analyses}

The analyses involved seventy nucleotide sequences and different reference sequences including all evolutionary lineages. Evolutionary analyses were conducted in MEGA7 (Kumar, Stecher, \& Tamura, 2016). DNA sequences were aligned using Muscle in the MEGA7 software. A phylogenetic tree was constructed with use of the Maximum Parsimony method (MP) using the clustal W-alignment (Chouhan \& Pardasani, 2008). Due to the large variation of sizes in the COI-COll region of $A$. mellifera the MP analysis was unrooted, the gaps were treated as missing characters, and no outgroup taxa was used. Parsimony bootstrap analysis included 1000 replicates (Felsenstein 1985) using the branch and bound algorithm. Branches corresponding to partitions that reproduced in less than 53\% bootstrap replicates were collapsed. The MP tree was obtained using the Subtree-Pruning-Regrafting (SPR) algorithm with search level 2 in which the initial trees were obtained by the random addition of sequences. After grouping the different samples, we recalculated the main morphometric parameters which were the cubital index, the total leg length, and the wing length per subspecies at the country level.

\section{RESULTS}

Molecular study: ecological gradient and honey bee morpho-ecotypes

The stepwise discriminant analysis of the morphometric characteristics revealed that the total leg length, the wing length and the cubital vein " $b$ " were the main morphometric measures that really discriminated the honey bee populations in the Republic of Benin $(P<0.001$ for the wing and the total leg length and $P<0.05$ for the cubital vein "b") (Tab. 1). The cubital index 
Table 2.

Morphometric characteristics of the different ecotypes and subspecies in the Republic of Benin

\begin{tabular}{|c|c|c|c|c|c|c|c|c|c|c|c|}
\hline & & & $\begin{array}{l}\text { Wing } \\
\text { length }\end{array}$ & $\begin{array}{l}\text { Wing } \\
\text { width }\end{array}$ & Vein a & Vein b & $\begin{array}{c}\text { Cubital } \\
\text { index }\end{array}$ & Femur & Tibia & Basitarsus & $\begin{array}{c}\text { Total } \\
\text { leg }\end{array}$ \\
\hline \multirow{6}{*}{ Ecotypes } & \multirow{2}{*}{ B-SG } & Avrg & 8.3 & 2.9 & 0.3 & 0.5 & 2.1 & 2.4 & 2.9 & 2.1 & 7.5 \\
\hline & & STDV & 0.2 & 0.1 & 0.0 & 0.1 & 0.4 & 0.1 & 0.1 & 0.1 & 0.2 \\
\hline & \multirow{2}{*}{ B-S } & Avrg & 8.5 & 3.0 & 0.3 & 0.5 & 2.1 & 2.5 & 3.0 & 2.2 & 7.7 \\
\hline & & STDV & 0.2 & 0.1 & 0.0 & 0.1 & 0.4 & 0.1 & 0.1 & 0.1 & 0.2 \\
\hline & \multirow{2}{*}{ B-DT } & Avrg & 8.7 & 3.1 & 0.3 & 0.6 & 2.0 & 2.6 & 3.1 & 2.2 & 7.9 \\
\hline & & STDV & 0.2 & 0.1 & 0.0 & 0.1 & 0.4 & 0.1 & 0.1 & 0.1 & 0.2 \\
\hline \multirow{6}{*}{ Subspecies } & \multirow{2}{*}{ adansonii } & Avrg & 8.6 & 3.0 & 0.3 & 0.5 & 2.0 & 2.5 & 3.0 & 2.2 & 7.7 \\
\hline & & STDV & 0.2 & 0.1 & 0.0 & 0.1 & 0.4 & 0.1 & 0.1 & 0.1 & 0.3 \\
\hline & \multirow{2}{*}{ iberiensis } & Avrg & 8.5 & 3.0 & 0.3 & 0.6 & 2.1 & 2.5 & 3.0 & 2.2 & 7.6 \\
\hline & & STDV & 0.2 & 0.1 & 0.0 & 0.0 & 0.4 & 0.1 & 0.1 & 0.1 & 0.2 \\
\hline & \multirow{2}{*}{ scutellata } & Avrg & 8.5 & 3.0 & 0.3 & 0.5 & 2.1 & 2.5 & 3.0 & 2.2 & 7.6 \\
\hline & & STDV & 0.2 & 0.1 & 0.0 & 0.1 & 0.4 & 0.1 & 0.1 & 0.2 & 0.3 \\
\hline
\end{tabular}

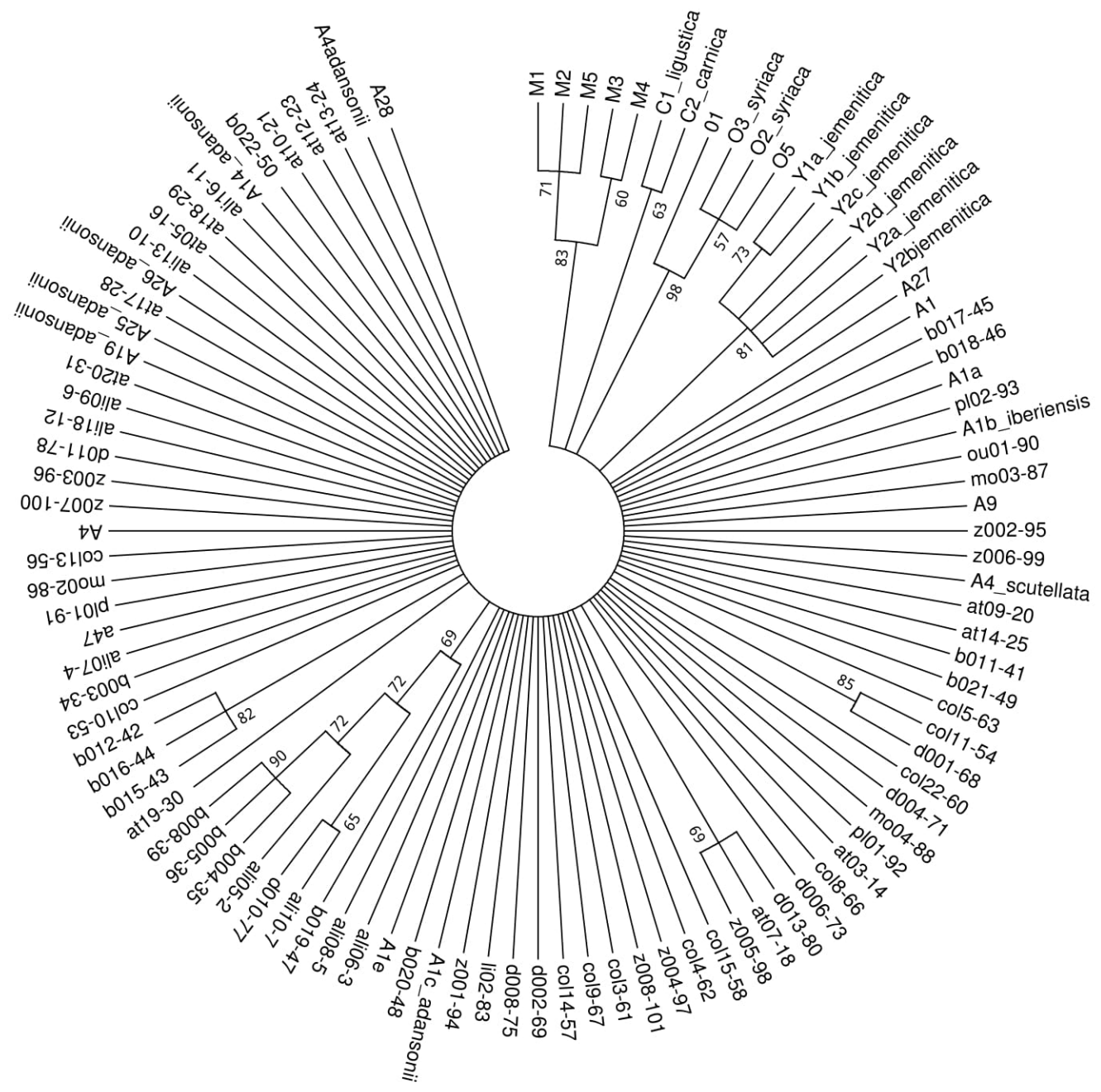

Fig. 4 Maximum parsimony phylogenetic tree of all analysed samples with other A. mellifera haplotypes which represents all five lineages. 
Table 3.

Haplotypes based on fragment length and SNP of mtCOI-COII intergenic region

\begin{tabular}{|c|c|c|c|c|c|}
\hline $\begin{array}{c}\text { Dral } \\
\text { haplotype }\end{array}$ & Location* & $\begin{array}{l}\text { Dral restriction } \\
\text { fragment length }\end{array}$ & N & $\begin{array}{l}\text { Haplotype } \\
\text { percentage }\end{array}$ & $\begin{array}{c}\text { \# SNP in Dral } \\
\text { haplotype }\end{array}$ \\
\hline \multirow[t]{3}{*}{ A1 } & C & 47108483 & 26 & 37,14 & \\
\hline & $\mathrm{N}$ & & 1 & 1,43 & 4 \\
\hline & S & & 4 & 5,71 & \\
\hline A1 VARIANT 1 & C & 47108482 & 1 & 1,43 & \\
\hline A1 VARIANT 2 & C & 47110483 & 3 & 4,29 & \\
\hline A1 VARIANT 3 & $S$ & 47107483 & 1 & 1,43 & \\
\hline \multirow[t]{3}{*}{ A4 } & C & 47108192483 & 3 & 4,29 & \\
\hline & $\mathrm{N}$ & & 3 & 4,29 & 2 \\
\hline & $S$ & & 1 & 1,43 & \\
\hline A4 VARIANT 1 & C & 47108191483 & 2 & 2,86 & \\
\hline A4 VARIANT 2 & C & 47108193483 & 1 & 1,43 & \\
\hline \multirow[t]{2}{*}{ A4 VARIANT 3} & C & 47108192486 & 2 & 2,86 & \\
\hline & $\mathrm{N}$ & & 4 & 5,71 & 3 \\
\hline A4 VARIANT 4 & $\mathrm{~N}$ & 47107192483 & 1 & 1,43 & \\
\hline A4 VARIANT 5 & $\mathrm{~N}$ & 47107192488 & 1 & 1,43 & \\
\hline A28 & C & 50109192191487 & 3 & 4,29 & \\
\hline A13 & $\mathrm{N}$ & 47302483 & 1 & 1,43 & \\
\hline QQ & C & 4740191484 & 3 & 4,29 & \\
\hline \multirow[t]{2}{*}{ QQQ } & C & 4740192192483 & 2 & 2,86 & \\
\hline & N & & 6 & 8,57 & \\
\hline QQQ' & C & $\begin{array}{cccc}47 \quad 40 & 192 & 192 & 63 \\
& 420 & \end{array}$ & 1 & 1,43 & \\
\hline
\end{tabular}

* $\mathrm{N}$ : northern part of the country - C: central part of the country - S: southern part of the country

did not differ significantly between the sampled colonies $(P=0.75)$, indicating that this parameter could not be used for typing the honey bee populations in the Republic of Benin.

The assessment of the effect of the geographic parameters (latitude, longitude and altitude) revealed that the bee total leg length and the wing length were highly determined by the latitude which respectively explained $29 \%$ $(P<0.001)$ and $37 \%(P<0.001)$ of the total difference in the bee leg and wing lengths, which in turn indicated a positive south-north gradient in bee size. On the other hand, the longitudes did not influence the morphometric parameters $(R=0.1$ and $P=0.1)$, and the different morphometric characteristics did not correlate with the amplitude in the elevation (14 $\mathrm{m}$ in the south to $405 \mathrm{~m}$ in the north-west) of the inspected apiaries ( $R=0.25$ and $P>0.10)$.

The discriminant analysis of the morphometric parameters indicated that the honey bees can be divided in three distinct groups (Fig. 2). The canonical function 1 explained $98.6 \%$ of the total variation and was determined by the total leg length and wing length. The canonical function 2 explained $1.4 \%$ of the total variation and was influenced by the cubital vein "b". The projection of the different groups over the country indicated that they were distributed in three particular regions that determined the honey bee ecotypes of the Republic of Benin (Fig. 3). The different morpho-ecotypes were named after their corresponding climate zone: Beninodry-tropical-ecotype (B-DTE) in the north, the Benino-Sudano-Guinean-ecotype (B-SGE) in the south and the Benino-Sudanian-ecotype (B-SE) 


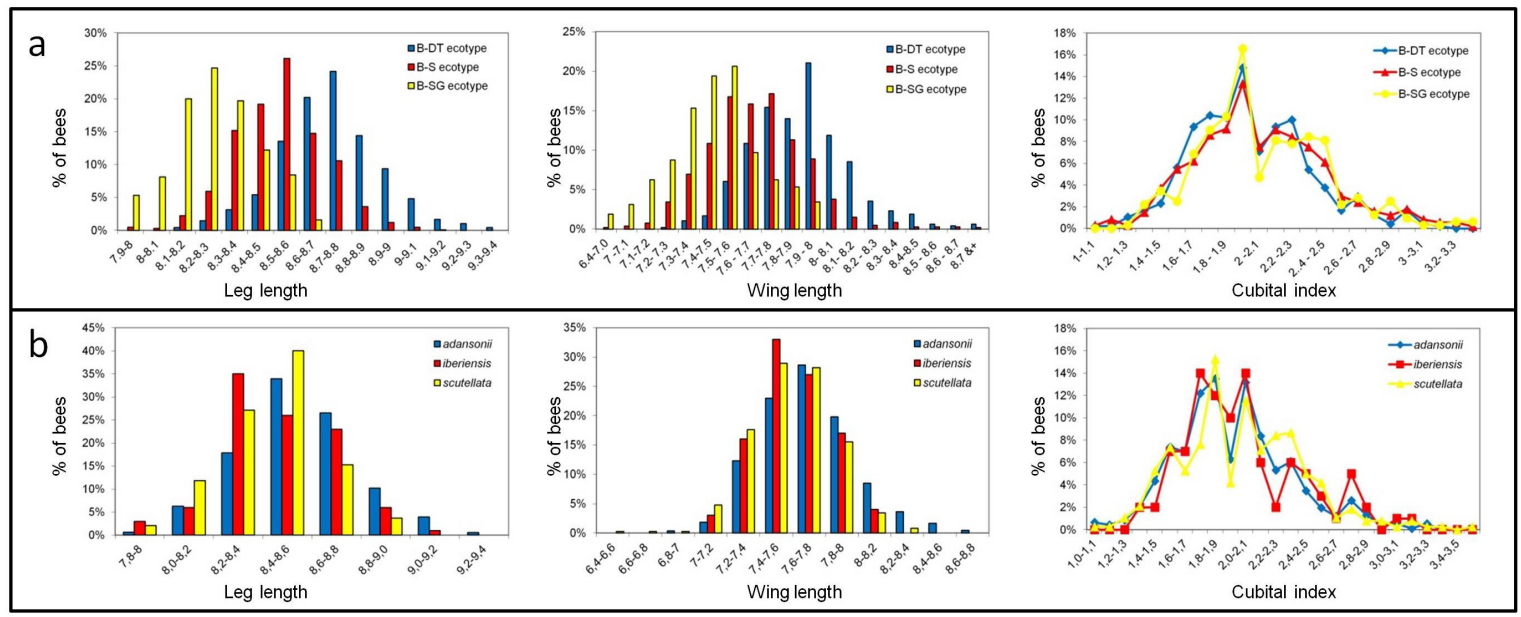

Fig. 5 Morphometric structure of the different honey bee ecotypes (panel a) and haplotype groups (panel b) in the Republic of Benin

in the centre. The morphometric parameters of each morpho-ecotype is summarised in Table 2. B-SGE: Benino-Sudano-Guinean-ecotype. B-SE: Benino-Sudanian-ecotype B-DTE: Benino-drytropical-ecotype. Avrg: Average; STDV: standard deviation. The morphometric parameters are in $\mathrm{mm}$.

\section{Molecular study: honey bee haplotypes}

DNA sequence for COI-COll region were obtained for seventy $A$. mellifera samples. Based on the Dral restriction pattern fifteen different haplotypes could be identified (Tab. 3), while for the sequence variations (single nucleotide polymorphism, SNP), nineteen haplotypes were distinguished. Three haplotypes were identical to previously described haplotypes (Acc. Ef033649.1; ef033650.1; gu326335.1). The other haplotypes were new and added to Genbank (Table 2). Almost all sequences showed a characteristic Dral restriction pattern that was typical for the A1, A4, A13 and A28 haplotype (Table 3). For three haplotypes a divergent Dral restriction pattern was observed. Further analysis showed that they missed the $P_{0}$ sequence which was until now a typical pattern for the A lineage and possessed two or three repetitions of the $Q$ sequence. Fig. 4 shows the phylogenetic tree of all analysed samples together with reference strains belonging to the $C, O, Y, M$ and $A$ lineage. All samples clustered together in the $A$ lineage and were clustering together with adansonii, scutellata or iberiensis subspecies. Based on these results the haplotypes were grouped and referred as respectively the adansonii group, scutellata group and iberiensis group. The morphometric parameters of these different groups were recalculated and were similar on the basis of the cubital index, the total leg length and the wing length (Fig. 5).

\section{DISCUSSION}

Morphometric diversity in the honey bees

We found that the high wing length amplitude (7 $\mathrm{mm}-8.5 \mathrm{~mm})$, the total leg length $(6 \mathrm{~mm}$ - $7 \mathrm{~mm}$ ) and the cubital index (1.04-3.7) corresponded with those found in earlier studies (Amakpe, 2010; Рaraïso et al., 2011). The high amplitude in the morphometric parameters was characteristic for honey bees from the Democratic Republic of Congo to Senegal, which belong to the adansonii subspecies (Franck et al., 2000a; Ruttner, 1988). The mean cubital index in the country $2.05 \pm 0.39$ is far below the cubital index in Cameroon and the whole of Africa (Ruttner, 1988). Based on the cubital index, our findings suggested that the bees of the Republic of Benin may be considered as a mixture of different subspecies or that the cubital index was not specific enough to discriminate between the different honey bee populations in the country.

Discriminant analysis showed the existence of three distinct groups, and spatial analysis 
showed that they clustered together (Fig. 3). The first morpho-ecotype, B-DTE, consisted of colonies which were entirely located in the dry tropical climate area which covered a distribution area of 5.008.637 ha (44\% of the country area) in the dry savannah. The third morphoecotype, was situated in the south of the country in the Sudano-Guinean climate whose distribution агеа covered 849.30 ha (8\% of the country area). These bees had the shortest legs and wings and were located in the south with vegetation originally from the Guineo-Congolian forest. The B-SGE ecotype was also observed in the relic forests of the central west. Between these two geographically opposite ecotypes, the second morpho-ecotype, B-SE, was situated with intermediate leg and wing length and higher cubital vein "b" index. The ecological distribution of this type covered a large area of 5.404 .259 ha (48\% of the country area) in the Sudanian climatic zone with the woodlands as dominant vegetation.

\section{Genetic diversity in the honey bees}

All analysed honey bees from the Republic of Benin belonged to the $A$ lineage. This was in correspondence with Franck et al. (2001) and Wallberg et al. ( 2014) who had determined that all honey bees in that part of Africa, including adansonii, scutellata and capensis subspecies belonged to the mitotypes of lineage $A$. Our finding also confirmed that honey bees from north-western Africa and from tropical and southern Africa highly diverged when mitochondrial and microsatellite data are considered (Franck et al., 2001). In fact, we found nineteen haplotypes out of the thirty already characterized for the whole A lineage (Clarke et al., 2001; Ilyasov et al., 2016) in the Republic of Benin.

All haplotypes had been fully characterized by sequencing, which explained the high number of different haplotypes/variants. Dral restriction fragments of many variants differed only in one nucleotide which would not be recognized by RFLP typing and could in fact be grouped under the SNP variations. These results indicated that using the Dral restriction pattern was not sufficient to explore the variation among samples and that sequencing was necessary for the complete exploration of variation as suggested previously (Cornuet \& Garnery, 1991; Magnus, Tripodi, \& Szalanski, 2011).

Furthermore, we found three novel mtDNA haplotypes which were grouped in the $A$ lineage based on the phylogenetic study. The identification of new haplotypes increases the diversity of haplotypes belonging to the A evolutionary lineage (Garnery et al., 1995 and Alburaki et al., 2011). The new haplotype was missing the $P_{0}$ segment in the intergenic region, which was characteristic for the $C$ lineage. Phylogenetic analysis clustered the new haplotype in the $A$ lineage possibly because of its duplication or triplication of the $Q$ regions which is in turn characteristic for the $A$ lineage.

A comparison of the genetic methods and the morphometry indicated that the morphoecotypes and the subspecies distribution areas in the Republic of Benin corresponded with each other (Fig. 6). In fact, the B-DTE was composed of the haplotypes grouped together with the adansonii subspecies in the north of the country. the B-SE was a mix of haplotypes grouped together with the scutellata, adansonii and iberiensis subspecies in the central Benin. The B-SGE ecotype was mainly made up of haplotypes which grouped together with the iberiensis and the adansonii subspecies in the southern part of the country.

Surprisingly there was no morphometric difference between the different grouped halpotypes in the country (Fig. 5) as they had the same cubital index, total leg and wing length distribution shape. The uniformity in the morphometry of the honey bee in each ecological area regardless their haplotype could then be considered as the results of specific natural selection forces which shaped the phenotype of the bee that had a highly diversified genetic origin (Ruttner, 1988; Sheppard et al., 1991; Sheppard \& Smith, 2000). The bigger size of the bees in the north may partially be explained by the adaptive behaviour of honey bees to the prevailing ecological conditions and stay more active and fly longer distances in open areas compared to closed forests making the forest ecotypes smaller than those of open lands 


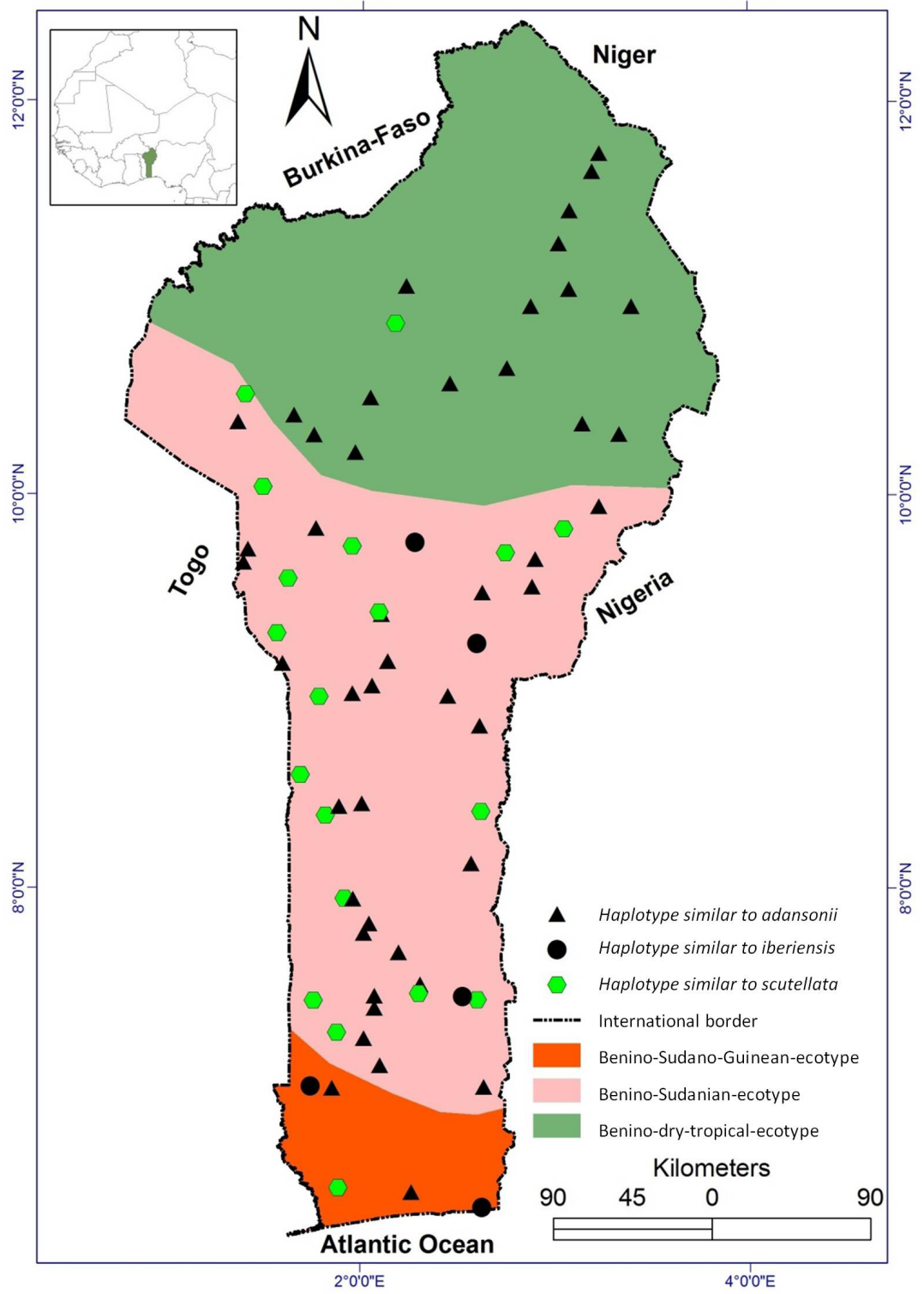

Fig. 6 Distribution of the different A. mellifera haplotype groups in the Republic of Benin.

(Adger, Arnell, \& Tompkins, 2005; Becher et al., 2010; Henle et al., 2004; Le Conte \& Navajas, 2008).

In conclusion, the honey bee genetic diversity in the Republic of Benin is made up of nineteen haplotypes from which sixteen had never described. Phylogenetic analysis showed that they could be clustered into three groups. These different groups cannot be distinguished by morphometric methods and were adapted separately to the different climatic conditions of the country making three different morpho-ecotypes. The research results indicated that morphometry can perfectly be used to determine the ecological diversity. As the morphometric parameters are influenced by the prevailing environmental conditions, only genetic methods could be used for the determination of the genetic diversity of the different bee species and their evolutionагу lineage.

\section{ACKNOWLEDGEMENTS}

This research is made possible by a funding from the International Foundation for Science (IFS) that we are extremely grateful thank. We also thank the NGO Cercle Nature et Development (CENAD$\mathrm{NGO}$ ) and the Centre Intégré d'Apiculture Tropical (CIAT-NGO) who helped in training the beekeepers and establishing the apiaries In the entire country.

\section{REFERENCES}

Adger, W.N., Arnell, N.W., \& Tompkins, E.L. (2005). Successful adaptation to climate change across scales. Global Environmental Change-Human and Policy Dimensions, 15, $77-$ 86. https://doi.org/10.1016/j.gloenvcha.2004.12.005

Adl, M.B.F., Gencer, H.V., Firatli, C., \& Bahreini, R. (2007). Morphometric characterization of Iranian (Apis mellifera meda), Central Anatolian (Apis mellifera anatoliaca) and Caucasian (Apis mellifera caucasica) honey bee populations. Journal of Apicultural Research, 46, 225-231. https://doi.org/1 0.1080/00218839.2007.11101399

Alburaki, M., Moulin, S., Legout, H., Alburaki, A., Garnery, L. (2011). Mitochondrial structure of Eastern honeybee populations from Syria, Lebanon and Iraq. Apidologie, 42, 628-641. DOl: 10.1007/s13592-0110062-4

Amakpe, F. (2010). The biodiversity of the honey 


\section{J. APPC. SOLI. VOL. Gi NO. 12018}

bees (Apis mellifera adansonil) in the District of Djidja, Republic of Benin. International Journal of Environmental, Cultural, Economic and Social Sustainability, 6, 90-104. DOl: 10.18848/1832-2077/CGP/ v06i06/54851

Amakpe, F., Zuber, S., \& Jacobs, F.. (2008). Role of beekeeping in the household food security and livelihoods: Implications for the sector policy development in Ethiopia. 2nd symposium University of Ghent, Gents Africa Platform.

Arias, M.C., \& Sheppard, W.S. (1996). Molecular phylogenetics of honey bee subspecies (Apis mellifera L) inferred from mitochondrial DNA sequence. Molecular Phylogenetics and Evolution, 5, 557-566. https:// doi.org/10.1006/mpev.1996.0050

Alattal, Y., Alsharhi, M., Alghamdi, A., Alfaify, S., Migdadi, H., Ansari, M. (2014). Characterization of the native honey bee subspecies in Saudi Arabia using the mtDNA COl-COll intergenic region and morphometric characteristics. Bulletin of Insectology, 67,31-37.

Becher, M.A., Hildenbrandt, H., Hemelrijk, C.K., \& Moritz, R.F.A. (2010). Brood temperature, task division and colony survival in honeybees: A model. Ecological Modelling, 227, 769-776. https://doi. org/10.1016/j.ecolmodel.2009.11.016

Bland, J.M., \& Altman, D.G. (1986). Statistical methods for assessing agreement between two methods of clinical measurement. Lancet, 7, 307-310. https://doi. org/10.1016/S0140-6736(86)90837-8

Bray, J.R., \& Curtis, J.T. (1957). An ordination of the upland forest communities of Southern Wisconsin. Ecological Monographs, 27, 326-349. DOl: 10.2307/1942268

Chemurot, M., Brunain, M., Akol, A.M., Descamps, T., de Graaf, D.C. (2016). First detection of Paenibacillus larvae the causative agent of American Foulbrood in a Ugandan honeybee colony. Springerplus, 5, 1090 DOl: 10.1186/s40064-016-2767-3

Chouhan, U., \& Pardasani, K. (2008). A maximum parsimony model to reconstruct phylogenetic network in honey bee evolution. International Journal of Biological and Medical Research, 3, 220-224.

Clarke, K.E., Oldroyd, B.P., Javier, J., Quezada-Euan, G., Rinderer, T.E. (2001). Origin of honeybees (Apis mellifera L.) from the Yucatan peninsula inferred from mitochondrial DNA analysis. Molecular Ecology, 10, 1347-1355.DOl: 10.1046/j.1365-294X.2001.01274.x

Cornuet, J.M., \& Garnery, L. (1991). Mitochondrial-DNA variability in honeybees and its phylogeographic implications. Apidologie, 22, 627-642. https://doi. org/10.1051/apido:19910606

Danforth, B.N., Cardinal, S., Praz, C., Almeida, E.A. Michez, D. (2013). The impact of molecular data on our understanding of bee phylogeny and evolution. Annual Review of Entomology, 58, 57-78. DOl: 10.1146/annurev-ento-120811-153633

Fazier, M., Muli, E., Conklin, T., Schmehl, D., Torto, B., Frazier, I., ... Raina, S. (2010). A scientific note on Varroa destructor found in East Africa; threat or opportunity? Apidologie, 47, 463-465. D0l: 10.1051/ apido/2009073

Felsenstein, J. (1985). Phylogenies and the comparative method. American Naturalist, 125, 1-15.

Franck, P., Garnery, L., Celebrano, G., Solignac, M., Cornuet, J.M. (2000a). Hybrid origins of honeybees from Italy (Apis mellifera ligustica) and Sicily ( $A-m$. sicula). Molecular Ecology, 9, 907-921. DOl: 10.1046/j.1365294x.2000.00945.x

Franck, P., Garnery, L., Loiseau, A., Oldroyd, B.P., Hepburn, H.R., Solignac, M., Cornuet, J.M. (2001). Genetic diversity of the honeybee in Africa: microsatellite and mitochondrial data. Heredity, 86, 420-430. DOl:10.1046/j.1365-2540.2001.00842.x

Franck, P., Garnery, L., Solignac, M., \& Cornuet, J.M. (1998). The origin of west European subspecies of honeybees (Apis mellifera): New insights from microsatellite and mitochondrial data. Evolution, 52, 1119 1134. DOI: 10.1111/j.1558-5646.1998.tb01839.x.

Franck, P., Garnery, L., Solignac, M., \& Cornuet, J.M. 
(2000b). Molecular confirmation of a fourth lineage in honeybees from the Near East. Apidologie, 37, 167-180. https://doi.org/10.1051/apido:2000114

Francoy, T.M., Wittmann, D., Drauschke, M., Muller, S., Steinhage, V., Bezerra-Laure, M.A.F., ... Goncalves, L.S. (2008). Identification of Africanized honey bees through wing morphometrics: two fast and efficient procedures. Apidologie, 39, 488-494. https://doi. org/10.1051/apido:2008028

Fresnaye, J. (1981). Biométrie de laabeille, UK: OPIDA.

Gallai, N., Salles, J.M., Settele, J., \& Vaissiere, B.E. (2009). Economic valuation of the vulnerability of world agriculture confronted with pollinator decline. Ecological Economics, 68, 810-821. https://doi. org/10.1016/j.ecolecon.2008.06.014

Garnery, L., Cornuet, J.M., \& Solignac, M. (1992). EvoIutionary history of the honey bee Apis mellifera inferred from mitochondrial DNA analysis. Molecular Ecology, 7, 145-154. DOl: 10.1111/j.1365-294X.1992. tb00170.x

Garnery, L., Franck, P., Baudry, E., Vautrin, D., Cornuet, J.M., Solignac, M. (1998). Genetic diversity of the west European honey bee (Apis mellifera mellifera and $A$. m. iberica). I. Mitochondrial DNA. Genetics Selection Evolution, 30, S37-S47. https://doi. org/10.1186/1297-9686-30-S1-S31

Garnery, L., Mosshine, E.H., Oldroyd, B.P., \& Cornuet, J.M. (1995). Mitochondrial-DNA Variation in Moroccan and Spanish Honey-Bee Populations. Molecular Ecology, 4, 465-471. DOl: 10.1111/j.1365-294X.1995. tb00240.x

Garnery, L., Solignac, M., Celebrano, G., \& Cornuet, J.M. (1993). A simple test using restricted PCR-amplified mitochondrial-DNA to study the genetic-structure of Apis mellifera L. Experientia, 49, 1016-1021. DOl: 10.1007/BF02125651

Garnery, L., Vautrin, D., Cornuet, J.M., \& Solignac, M. (1991). Phylogenetic-relationships in the genus Apis inferred from mitochondrial-DNA sequence data. Apidologie, 22, 87-92. https://doi.org/10.1051/api- do:19910111

Henle, K., Davies, K.F., Kleyer, M., Margules, C., Settele, J. (2004). Predictors of species sensitivity to fragmentation. Biodiversity and Conservation, 13, 207251. DOl: 10.1023/B:BIOC.0000004319.91643.9e

Hounpke, N.U.H., Mensah, G.A., Koutinhouin, B., Pomalegni, S.C.B., Goergen, G. (2007). Characterization of honeybees in Nothern Benin. Bulletin de la Recherch Agronomique du Bénin, 58, 56-59.

Ilyasov, R.A., Poskryakov, A.V., Petukhov, A.V., \& Nikolenko, A.G. (2016). New approach to the mitotype classification in black honeybee Apis mellifera melifera and Iberian honeybee Apis mellifera iberiensis. Russian Journal of Genetics, 52, 281-291. DOl: 10.1134/S1022795416020058

Jaffe, R., Dietemann, V., Crewe, R.M., \& Moritz, R.F.A. (2009). Temporal variation in the genetic structure of a drone congregation area: an insight into the population dynamics of wild African honeybees (Apis mellifera scutellata). Molecular Ecology, 18, 1511-1522. DOI: 10.1111/j.1365-294X.2009.04143.x.

Javier, J.G., Quezada-Euan, J.J.G., Paxton, R.J., Palmer, K.A., Itza, W.D.M., Tay, W.T., Oldroyd BP. (2007). Morphological and molecular characters reveal differentiation in a Neotropical social bee, Melipona beecheii (Apidae : Meliponini). Apidologie, 38, 247-258, https://doi.org/10.1051/apido:2007006

Kumar, S., Stecher, G., \& Tamura, K. (2016). MEGA7: Molecular Evolutionary Genetics Analysis Version 7.0 for Bigger Datasets. Molecular Biology and Evolution, 33, 1870-1874. DOl: 10.1093/molbev/msw054

Le Conte, Y., \& Navajas, M. (2008). Climate change: impact on honey bee populations and diseases. Revue Scientifique Et Technique, 27, 485-497, 499510.

Magnus, R.M., Tripodi, A.D., \& Szalanski, A.L. (2011). Mitochondrial DNA diversity of honey bees, Apis Mellifera L. (Hymenoptera: Apidae) from queen breeders in the United States. Journal of Apicultural Science, 55(1), 37-46. 


\section{ป. APIC. SCL. VQL. 62 NO. 12018}

Meixner, M.D., Leta, M.A., Koeniger, N., \& Fuchs, S. (2011). The honey bees of Ethiopia represent a new subspecies of Apis mellifera-Apis mellifera simensis n. ssp. Apidologie, 42, 425-437. DOl: 10.1007/ s13592-011-0007-y

Miguel, I., Baylac, M., Iriondo, M., Manzano, C., Garnery, L., Estonba, A. (2011). Both geometric morphometric and microsatellite data consistently support the differentiation of the Apis mellifera M evolutionary branch. Apidologie, 42, 150-161. https://doi. org/10.1051/apido/2010048

Moritz, R.F.A., de Miranda, J., Fries, I., Le Conte, Y., Neumann, P., Paxton, R.J. (2010). Research strategies to improve honeybee health in Europe. Apidologie, 47, 227-242. https://doi.org/10.1051/apido/2010010

Ogbuehi, K.C., \& Osuagwu, U.L. (2012). Repeatability and interobserver reproducibility of Artemis-2 highfrequency ultrasound in determination of human corneal thickness. Clinical Ophthalmology, 6, 761769. DOI: 10.2147/OPTH.S31690

Paraïso, A., Viniwanou, N., Akossou, A.Y..., Mensah, G.A., Aboila, W. (2011). Caractérisation morphométrique de l'abeille Apis mellifera adansonii au NordEst du Bénin. International Journal of Biological and Chemical Sciences, 5, 331-344. D01:10.4314/ijbcs. v5i1.68109

Paraïso, A., Paraïso, G., Salako, V., Abiola, W., Kelomey, A., Glele Kakaï, R., ... Glitho, A.I. (2016). Compliance of the morphometric characteristics of Bees in Benin with those of Apis mellifera andansonii. Journal of Entomology, 14, 24-32. DOl: 10.3923/je.2017.24.32

Ruttner, F. (1988). Biogeography and taxonomy of honey bees. Berlin, Heidelberg, New York.

Ruttner, F., Tassencourt, L., \& Louveaux J. (1978). Biometrical-statistical analysis of the geographic variability of Apis mellifera L .1. Material and Methods. Apidologie, 9, 363-381.

Sheppard, W.S., Rinderer, T.E., Mazzoli, J.A., Stelzer, J.A., Shimanuki, H. (1991). Gene flow between Af- rican-derived and European-derived honey-bee populations in Argentina. Nature, 349, 782-784. DOl:10.1038/349782a0

Sheppard, W.S., \& Smith, D.R. (2000). Identification of African-derived bees in the Americas: A survey of methods. Annals of the Entomological Society of America, 93, 159-176. DOl: 10.1603/0013-8746(2000)093[0159:IOADBI]2.0. $\mathrm{CO}, 2$

Shrestha, S., \& Kazama, F. (2007). Assessment of surface water quality using multivariate statistical techniques: A case study of the Fuji river basin, Japan. Environmental Modelling \& Software, 22, 464 475. https://doi.org/10.1016/j.envsoft.2006.02.001

Strauss, U., Human, H., Gauthier, L., Crewe, R.M., Dietemann, V., Pirk C.W.W. (2013). Seasonal prevalence of pathogens and parasites in the savannah honeybee (Apis mellifera scutellata). Journal of Invertebrate Pathology, 174, 45-52. DOl: 10.1016/j. jip.2013.05.003

Villières, B. (1987). L'apiculture en régions tropicales et équatoriales de l'Oest. Bulletin Technique Apicole, 14, 193-220.

Wallberg, A., Han, F., Wellhagen, G., Dahle, B., Kawata, M., Haddad, N., ... Webster, M.T. (2014). A worldwide survey of genome sequence variation provides insight into the evolutionary history of the honeybee Apis mellifera. Nature Genetics, 46, 1081-1088. DOl: 10.1038/ng.3077 
